\title{
Leadership, circuition, and shift in tabletop wargaming community
}

\section{Jacek Mianowski}

Kazimierz Wielki University in Bydgoszcz

jacek.m@ukw.edu.pl | ORCID: 0000-0003-3408-4444

\begin{abstract}
The following paper seeks to address the idea of a player community's life cycle in a holistic way by shedding light on key issues related to the creation of wargaming groups, sustaining these groups and their mechanisms of decay. It encompasses a variety of ethnographic data, gathered from the communities of: Flames of War, Warmachine \& Hordes as well as the Star Wars franchise. Bearing in mind that the research is ongoing, the paper incorporates various data gathered in the course of the last three years, including participant observation, fieldwork notes, player interviews, and online discussions.
\end{abstract}

Keywords: tabletop wargaming, speech community, game life cycle

Homo Ludens 1(13)/2020 | ISSN 2080-4555 | ๔ Polskie Towarzystwo Badania Gier 2020 DOI: $10.14746 /$ HL.2020.13.8 | received: 12.09 .2020 | revision: 29.09.2020 | accepted: 11.12 .2020 



\section{Introduction}

Tabletop wargaming, seen as a past-time and hobbyist activity (Featherstone, 1998), may be considered a powerful tool not only in transforming its participants, but also in internalising their experiences. Wargaming constitutes a high-engagement activity in which players are put in a situation where they learn to deal with both making difficult decisions and taking the responsibility for their results (Perla, McGrady, 2011). It can become a potent tool in education and training (Reynaud, Northcote 2015; MacNab, 2012), a facilitator of social interaction, and a key to successful pastime.

While bearing in mind the emphasis on hobbyist activities, we should also note that wargaming provides unique circumstances for culture creation. By means of participation, it establishes a meaningful discourse for interaction and facilitates the formulation of new speech communities (Duranti, 1997; Foley, 1997). What is more, it establishes a system of practices in terms of participation and interaction.

From a historical point of view, wargaming was deeply rooted in the military entourage, yet its main premise was not to conduct warfare, but to train and prepare for unprecedented or unforeseeable situations. Initially, the term was used in the military context, as the origin of wargames can be traced to 19th-century training programmes for officers (von Hilgers, 2000; MacNab, 2012).

Both historical and fantasy tabletop wargames are witnessing a period of increased popularity in Poland. Gamer communities may focus around one of several motivating factors, including a league system; casual, weekend games of small groups; or the need to tamper or power-game a system (Carter, Harrop, Gibbs, 2014a, 2014b). In such cases, communities may integrate between two (with focus on niche, historical games, for instance, Chain of Command) and two-hundred players (Star Wars: X-Wing Miniature Game), depending on the game itself. Yet, the majority of these communities undergo a chronotope of changes that can be perceived as a life-cycle.

\section{Research methodology}

In the following paper I seek to present a narrow slice of an ongoing research project focused on wargaming communities in Poland. Since 
its inception in 2015 , I have focused on larger cities, usually voivodeship capitals, as these are most likely to agglomerate an adequate number of players and are a base for hobby shops and gaming clubs that become the heart and soul of the wargaming hobby.

My research utilises an ethnographic approach, with the researcher taking the role of a player and becoming a member of studied communities. This allows "a way of seeing through participants' eyes: a grounded approach that aims for deep understanding of the cultural foundations of the group" (Hine, 2000, p. 21). In this perspective, the playerresearcher goes through all the stages of becoming a community citizen (Block, 2009), participating in organized play, socialising, and finally taking on the role of a mentor for younger players. There are substantial similarities here to Gary Alan Fine's ethnographic study of roleplaying games (Fine, 1983/2002), especially in terms of the phases of the player's (researcher's) initiation into the community.

In my research I have focused on different pieces of data, including field notes from participant observation, semi-structured interviews carried out with players, and socialising in informal situations (cf. Brown 2015; Carter, Harrop, Gibbs, 2014a, 2014b). For the purpose of this particular paper I will demonstrate the information and observations gathered while researching one particular wargaming community, focused on Flames of War (abbreviated as Fow).

Aside from participating in various forms of structured play, players communicate on a regular basis through social media (Facebook groups), internet forums, but mostly through daily conversations. It can be argued that the Internet is the most prolific means of exchanging ideas due to the fact that players live in various cities. Facebook seems to be the dominant medium, yet online message boards, although in decline, still carry some importance. ${ }^{1}$ The usual array of activities include tournaments, discussions of current affairs, sharing and commenting photos, tips for modelling, arguing over the game rules, composing army lists, as well as trading miniatures by means of a separate Facebook group.

1 In the case of Fow, Polish forums are managed by one of the several official game retailers. 
Flames of War is a World War II tabletop miniature wargame produced by the New Zealand company Battlefront Miniatures Ltd (Yates, Turner, 2017). The first edition of its rules was released in 2002, with a later spinoff Team Yankee (Yates, 2015), set in a hypothetical cold-war-going-hot scenario in 1985, in Central Europe, and related to a novel of the same title by Harold Coyle (1987). In terms of gameplay, Fow tries to recreate a military conflict in a fairly believable way, i.e. through the use of maps and terrain, varied unit characteristics, by using dice rolls to determine game outcomes, and employing scale miniatures. At the same time, game authors have given players the possibility to both recreate historical battles (through dedicated book supplements) and to play competitively, usually in some form of organised play.

Organised play remains a hot topic among fow players, who approach their hobby competitively. To this extent players have devised a league system, focused around tournaments. The 2019/20 league season scoreboard ${ }^{2}$ listed 86 players, out of which around 50 remain active and participate in this form of organised play. The Polish league has gained a fair extent of international recognisability, which resulted in foreign participation in Polish tournaments. There were six players from Belarus, Portugal, Germany, and the Czech Republic participating in tournaments in the so-called league centres: Poznań, Bydgoszcz, Warsaw, Wrocław, Kraków, Głogów, Zielona Góra, with each city amassing its own fow community, comprising of between four and twenty players. There seem to exist a magnitude of reasons and motivations for playing fow competitively, ranging from casual players, to tournament result-oriented ones, to local pace-setters or leaders that attempt to stimulate their local communities to participate more actively.

\section{Founding a community}

The process of evolution of a tabletop wargaming community runs through three stages that correspond with the model of Peter Block (2009). It begins with a small, dedicated group of enthusiasts seeking to engage

$2<$ https://tournykeeper.com/\#/ranking/50>, accessed 5 December 2020. 
a larger amount of players. In addition to non-competitive casual games, the dynamics of the evolution involve dedicated leadership, focused on transforming to the second stage of evolution, where a group of around ten players engage in various forms of organised play. The success of this stage relies not only on the game publishers' support, but mostly on the support of local hobby shops and gaming clubs, societies, and public institutions that provide the venue and deal with the logistics. The final step integrates players on the national and international levels through events, tournaments, and championships. It establishes a setting for competitive play and social interactions, as well as for professional gaming. Finally, there are several mechanisms responsible for the decay and dissolution of wargaming communities, based on social factors (negative interactions) or the game meta (Mauger, 2016).

In order to invigorate a wargaming community, several issues have to be taken into consideration. One of them is community health (cf. Block, 2009, p. 17), which depends on the level of social capital. This is achieved through gaining a certain level of cohesion among the community members. In other words, players need to interact but they also need to take care of the social aspect of their interactions.

Forming a new wargaming community often takes place through the engagement of players from an already-existing community, and there are two notions that allow the initial stage to go through. These are the game itself - which should appeal as engaging and interesting in a way that attracts more players - and developing a gaming experience where new players feel both welcome and connected to others (Putnam, 2000). In other words, the safety and success of an individual depend on other players.

Social capital, understood as a widespread relatedness among players, builds up gradually, in small steps (Block, 2009, pp. 17-20). A wargaming community in its infancy consists of at least two players willing to share a game. If the game shows potential, there appears an incentive to invite others. This usually takes place among friends or colleagues, and depends on the game itself. Anything, from the novelty of the game rules, to the aesthetics of minifigures, the accessibility of the game, the price range for game starter sets, to the game setting (historical, sci-fi, or other) may factor towards the success. Some games are well-marketed from the start, be it through the publisher's effort or word-of-mouth; some are designed 
to easily attract large masses of people to play and participate in events. The latter characteristic is the foundation of success for Star Wars: X-Wing Miniature Game, as it combines features and game mechanics shared by both board- and wargames.

\section{Stage I: Small group dynamics}

One of the basic (though not necessarily conscious) needs that an individual seeks to satisfy when joining a wargaming community is the need for belonging. It becomes the goal of an individual as well as a community matter (Block, 2009, pp. 2-9). In this regard the process of community building is an aggregation of small steps that range from inviting people to participate, organising events with rewards (i.e. local tournaments, where all new players receive rewards for participating), advising on new purchases, consulting game rules, developing modelling and hobby techniques, to even more detailed issues, for instance, personally inviting players to come and making sure they will make it. In other words, new members need to feel that they are welcome and needed within the community. This is what Block (2009, p. 3) calls the rule of hospitality (being welcoming) and generosity (offering with no expectations in return).

This stage of development is not only the most significant; it also takes the most time and effort. There are a myriad of things that can go wrong, and even if everything proceeds as planned, people may feel pushed away by the smallest detail. Typically, players mention the lack of time or financial resources, becoming bored or dissatisfied with the game, and sometimes interpersonal issues (and thus the feeling that one does not fit in).

\section{Stage II: Organised play}

When a given wargaming community is growing steadily, it develops certain habits and a specific type of sociolect (Matyka, 2014) that make it unique. After a time, when the group grows to six or more active players, there arises the need to organise structured events - tournaments or campaigns. Typically, such events are announced publicly to encourage 
players from other cities to participate. It is also worth mentioning that aside from socialising, structured play events are organised to integrate the local group into a larger social organism. Players receive rewards not only for participation, but also for taking top (and last) places.

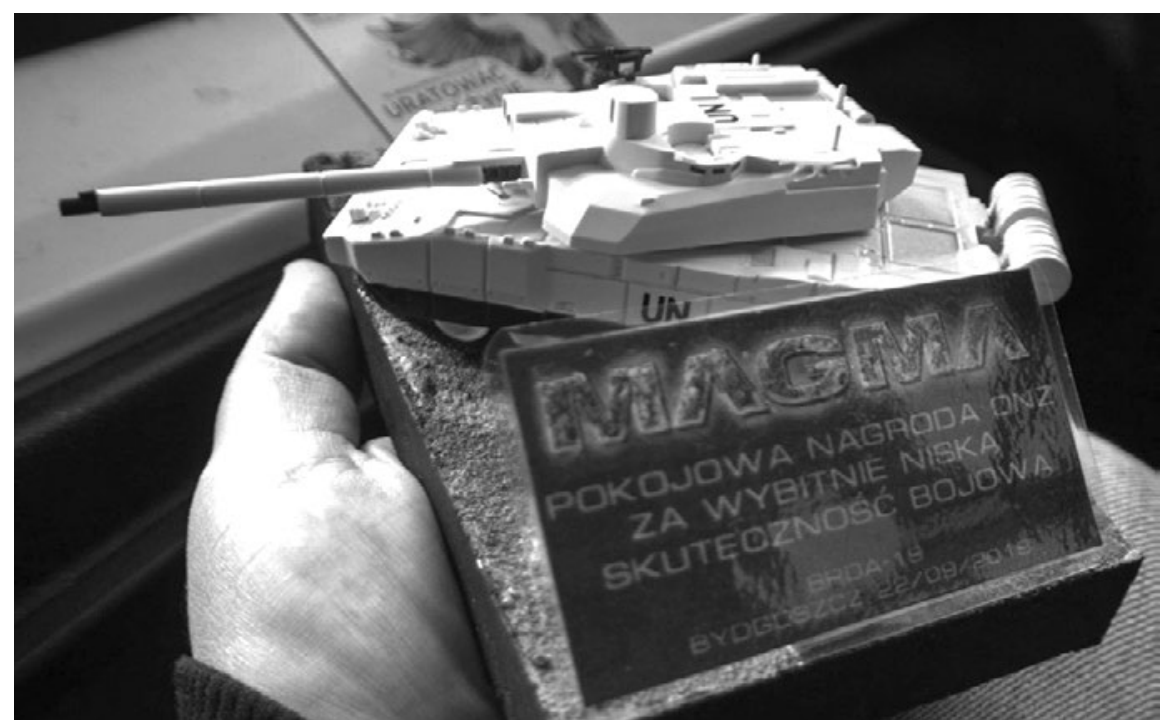

Figure 1. A diorama trophy, awarded for taking the last place at a Fow / Team Yankee tournament: "un Peace Prize for remarkably low combat efficiency." Photo by the author

Participation in organised play results from the will to compete and win, but it is grounded in social bonds, too. Players choose to believe that the group to which they belong is worth investing their time and resources. This is also the point where conscious decisions regarding the scope of participation are being made. Thus, players make a choice not only to come and take, but also to invest their time in teaching game rules to others, providing introductory games, or organising modelling workshops. At this point players become what Peter Block (2009) would call citizens. There is also a financial dimension, as some players are willing to invest both their time and private resources in the form of tournament infrastructure or rewards, occasionally even brokering new or used models at attractive prices, at times with little profit, because "they need people to play a game with." 


\section{Community in decline}

Rapid development of wargaming communities may have negative consequences. Although conflicts are a natural occurrence in player communities, in the context of wargaming they revolve around the fact that the majority of social interactions are handled face to face. In the course of various interpersonal conflicts individual gains and goals may become more important than the goals of the whole. This results in various forms of power struggles and "calling the shots", single-handedly deciding on "what we are playing, when, what point values for army lists we are using, or who can play with us." This is when players start to see that the way things are being said and presented has a fundamental impact on the health of their community. The power of both negative and positive language impacts those directly engaged in current activities; it may also result in collateral damage. Discussions carried out on Facebook groups are visible to the public and once a discussion gets out of hand, it becomes effective at repelling new players and interested bystanders from participation. The fallout is usually difficult to manage and takes extra time and care to make amends.

After some time, negative forms of communal teaching stories (Block, 2009, p. 35) lose their publicity and stop being viewed as attractive. This is when community members start to realise that such arguments do not actually constitute anything new, and that they focus on going over and over the same old issues instead. Departing from the culture of retribution (Block, 2009, pp. 40-43) with autocratic tendencies and strong leaders ends the dependency and entitlement of citizens. Once the past becomes the past, and getting a grasp of the thought about a better community begins to be possible, new ideas become easier to implement.

Fluctuating within a highly-competitive environment, wargamers provide various reasons and justifications for quitting or changing the preferred game system:

I've achieved enough in Fow. I got to the top of the ladder and went to $\operatorname{ETC}^{3}$ three times, every time scoring a top place. No more winning trophies or trinkets for me here. I don't like the new v. 4 Fow rules. They've reset the meta, took out all the fun of special rules.

3 European Tabletop Championships, <https://www.etc-tabletop.com/>, accessed 5 September 2020. 
The gradual decline in the amount of players becomes even more drastic if the quitting parties involve community leaders. A leaderless community is being dragged into a power struggle, with several individuals willing to issue commands and allocate tasks, and with little effectiveness in terms of organising tournaments, providing introductory games, or setting up regular events at a local hobby shop. By assigning fault and intercalating anxiety the associational life is gradually marginalised.

The word of mouth concerning the state of affairs travels fast, while the concern for the game system decreases. This leads directly to the departure of a majority of players and thus, a wargaming community is brought close to death. However, the loss of interest in the system is not always permanent, as there usually remains a small group of enthusiasts willing to play from the comfort of their own homes. Just as a new edition of game rules may act as a deterrent for some, it can also prove to be an asset in recruiting returning players. Players consciously choose to be accountable rather than entitled, and, as Peter Block puts it,

[c]itizenship as the willingness to build community gets displaced by isolationism in any form. It is not by accident that the loudest activists for finding and deporting undocumented workers are some of the leaders of the fear, oversight, safety, and security agenda. They are the key beneficiaries of the retributive society. If we want community, we have to be unwilling to allow citizenship to be co-opted in this way.

The idea of what it means to be a citizen is too important and needs to be taken back to its more profound value. Citizenship is a state of being. It is a choice for activism and care. A citizen is one who is willing to do the following:

- Hold oneself accountable for the well-being of the larger collective of which we are a part.

- Choose to own and exercise power rather than defer or delegate it to others.

- Enter into a collective possibility that gives hospitable and restorative community its own sense of being.

- Acknowledge that community grows out of the possibility of citizens. Community is built not by specialized expertise, or great leadership, or improved services; it is built by great citizens.

- Attend to the gifts and capacities of all others, and act to bring the gifts of those on the margin into the center (Block, 2009, p. 65).

The small batch of eager players who still see a possible way out try to re-animate the community, while bearing in mind that a shift in the quality of language - from conversations about the past to conversations about possibilities and refocusing goals - is the key to success. 


\section{Stage III: (Inter)national scale play}

Once a wargaming community is satisfied with the frequency and attendance of locally-organised play events, it starts to look for ways to compete on a larger scale. This is what wargamers often call "the tournament hunger." Large-scale tournaments - called nationals or grand tournaments are treated as open events, where anyone can participate, yet their prestige and importance within communities is greater in comparison to localscale events. Not only do players compete for the top places and trophies but they also negotiate the social hierarchy. There is also a statistical and mathematical side of larger events. Nationals and grand-scale tournaments, which may attract twenty (Star Wars: Armada Grand Tournament 2017 ${ }^{4}$ ), fifty (Warmachine $\mathcal{E}$ Hordes: Guildmachine Warball 2019 - Deutsche Meisterschaft, Hamburg5; Warmachine \& Hordes: Drużynowy Turniej Miast, Pruszków ${ }^{6}$ ), or even over a hundred players (Star Wars: X-Wing Miniature Game Polish Grand Championship $p^{7}$ ), are statistically-viable events that allow to check the current game mechanics in practice, and see which army construction strategies and gameplay tactics make the most sense.

The scale and logistic requirements make such tournaments popular and well-attended events. Their popularity reaches beyond Polish borders, with foreign players' participation at around 5-10\% of all players, depending on the system. One of the factors in deciding on tournament participation is the game meta, as there is a popular claim among tournamentoriented wargamers that it is a well-composed army list, and not the player, that wins matches. Meta-gaming is understood here as employing the rules "against" their original purpose, that is, searching for flaws in the game rules and using them for their own benefit. As Vincent Mauger observes,

[f]or some players, game is serious business. Total control of its system, for the sake of extreme efficiency, can become detrimental to the recreational activity itself as it is built in collaboration with other players who do not necessarily share the

\footnotetext{
4 <https://www.facebook.com/events/1431921283518294/?active_tab=about >, accessed 5 September 2020.

5 <https://www.tabletoptournaments.net/de/t3_tournament_results.php?tid=22422>, accessed 5 September 2020 .

${ }^{6}<$ https://tournykeeper.com/\#/tournament/details/922>, accessed 5 September 2020.

7 <https://listfortress.com/tournaments/1292>, accessed 5 September 2020.
} 
same commitments. Some strategies, actions or methods used by these metagamers transcend established rules. Implicit rules of social order are ignored to achieve better performance, and formal rules are sometimes thwarted by the use of shortcuts and loopholes allowed by the system (such as exploits) or simply dominant strategies imbalanced by designers (Mauger, 2016).

This aspect can be treated as an inherent feature of a vast majority of wargaming systems nowadays. However, meta-gaming is not necessarily a negative phenomenon, as a good knowledge of the system and its mechanics is one of the reasons behind the success of national teams at international and world-wide tournaments, including the aforementioned ETC. In other words, getting a good grasp of the game meta, understanding the mechanics behind the system, building diversified, so-called "all-rounder" lists become a game within a game (Carter, Harrop \& Gibbs, 2014a, 2014b). Army lists are adapted from tournament to tournament, while within some game systems (i.e. Warmachine $\mathcal{E}$ Hordes) the game meta changes periodically due to minor tweaks within unit statistics introduced by the designers.

\section{Conclusions}

When one puts the emphasis on hobbyist activities, wargaming provides unique circumstances for culture creation. By means of participation, it establishes a meaningful discourse for interaction and facilitates the formulation of new speech communities. What is more, it establishes a system of practices in terms of participation and interaction. One of the key concepts in the success of a wargaming community can be summarised by a quote from one of the players, concerning the scale of his time and resource investments into the development of his community. The reason behind this is that "I want to have people to play this game with."

From an outsider's perspective, wargamers may come across as accustomed to the state of affairs where they arrive at a prepared event without the need of any input on their behalf. This may lead to an attitude of entitlement and ignites internal conflicts that may result in the death of a given community. Therefore, the sustainability of a community boils down to three key elements. Firstly, there always has to be a group 
of engaged players, willing to take action, while bearing in mind that in terms of tournament preparations and logistics, setting tables and terrain pieces, or cleaning the venue after the event is over, they may not get the help they need and no one will thank them. Secondly, it is vital that the community use all the support they can get, by means of a local hobby or game store, as well as from game publishers, who often help with organising events by pledging rewards. And finally, one has to bear in mind that a particular game needs to prove to be adequately attractive to players.

\section{References}

Block, P. (2009). Community: The Structure of Belonging. Berrett-Koehler Publishers Inc.

Brown, A. (2015). Awkward: The Importance of Reflexivity in Using Ethnographic Methods. In P. Lankoski, S. Björk (eds.), Game Research Methods: An Overview (pp. 77-92). ETC Press.

Carter, M., Harrop, M., Gibbs, M. (2014a). The Roll of the Dice in Warhammer 40,000. In F. Mäyrä, K. Heljakka, A. Seisto (eds.), ToDIGRA: Physical and Digital in Games and Play (pp. 1-28). Pittsburgh: ETC Press.

Carter, M., Harrop, M., Gibbs, M. (2014b). Drafting an Army: The Playful Pastime of Warhammer 40,000. Games and Culture, 9 (2), 122-147.

Coyle, H. W. (1987). Team Yankee: A Novel of World War III. New York: Presidio Press.

Duranti, A. (1997). Linguistic Anthropology. Cambridge: Cambridge University Press.

Featherstone, D. (1988). Featherstone's Complete Wargaming. London: David \& Charles.

Fine, G. A. (1983/2002). Shared Fantasy: Role-Playing Games as Social Worlds. Chicago, London: The University of Chicago Press.

Foley, W. (1997). Anthropological Linguistics: An Introduction. Blackwell Publishers Ltd.

von Hilgers, P. (2000). Eine Anleitung zur Anleitung. Das Takstische Kriegsspiel 1812-1824. Board Games Studies: International Journal For the Study of Board Games, (3/2000), 59-78.

Hine, C. (2000). Virtual Ethnography. London: Sage. 
Mauger, V. (2016). From Metagaming to Metadesign: Designing Actively Beyond Rules and Borders. Digital Games as History. How Videogames Represent the Past and Offer Access to Historical Practice. Paper presented at Intelligences Numériques - Digital Intelligence Conference. 4-6 April 2016, University of Laval.

MacNab, I. A. (2012). Kriegsspiel and the Sandtable: Using Tabletop Wargames to Teach Tactics and Exercise Decision Making in the Classroom. Unpublished MA dissertation. New York: Center for Teaching Excellence, United States Military Academy, West Point.

Matyka, M. (2014). Socjolekt uczestników klasycznych gier fabularnych jako profesjolekt. Homo Ludens, 6(1), 101-115.

Perla, P. P., McGrady, E. (2011). Why Wargaming Works. Naval War College Review, Summer 2011, 64(3), 1-20.

Putnam, R. D. (2000). Bowling Alone: The Collapse and Revival of American Community. New York: Simon\& Schuster.

Reynaud, D., Northcote, M. (2015). The World Wars Through Tabletop Wargaming: An Innovative Approach to University History Teaching. Arts \& Humanities in Higher Education 2015, 14(4), 349-367.

\section{Ludography}

Clarke, R. (2013). Chain of Command. Rules for wwiI Platoon Level Combat. Too Fat Lardies. Online: <https://toofatlardies.co.uk/product/chain-ofcommand-rules-ultimate-bundle/>, accessed 5 September 2020.

Little, J. (2012). Star Wars: X-Wing Miniatures Game. Fantasy Flight Games, USA. Online: <https://www.fantasyflightgames.com/en/products/xwing-second-edition/>, accessed 5 September 2020.

McVey, M., Snoddy, B., Wilson, M. (2019). Warmachine \& Hordes. New Rules Digest. Privateer Press, USA. Online: $<$ https://privateerpress.com/ organized-play/game-rules-errata $>$, accessed 5 September 2020.

Kniffen, J., Petersen, C.T. (2015). Star Wars: Armada. Rules Reference. Fantasy Flight Games, USA. Online: <https://www.fantasyflightgames. com/en/products/star-wars-armada/>, accessed 5 September 2020.

Yates, P. (2015). Team Yankee: World War III. Battlefront Miniatures Ltd, New Zealand. 
Yates, P., Turner W. (2017). Flames of War: The World War II Miniatures Game. 1939-41 and 1944-45. Battlefront Miniatures Ltd, New Zealand.

Jacek Mianowski, PhD - Assistant Professor at the Institute of Modern Languages and Applied Linguistics at Kazimierz Wielki University in Bydgoszcz, Poland. His areas of academic research include anthropological linguistics, ethnography of communication, emergence and evolution of writing systems, and game studies

\title{
Przywództwo, cykliczność i zmiany w społeczności gier bitewnych
}

\begin{abstract}
Abstrakt: Poniższy artykuł jest próbą holistycznego odniesienia się do idei cyklu życia społeczności graczy. Rzuca światło na kluczowe kwestie związane z tworzeniem grup graczy gier bitewnych, podtrzymywaniem tych grup przy życiu i ich mechanizmów rozpadu. Artykuł oparty jest na różnorodnych danych etnograficznych, zebranych z trzech społeczności związanych z grami: Flames of Wari Warmachine \& Hordes, a także z uniwersum Star Wars. Ze względu na to, że badania podczas powstawania tekstu nie były jeszcze zakończone, publikacja oparta jest na danych zgromadzonych w ciągu trzech ostatnich lat, w tym obserwacjach uczestników, notatkach z badań terenowych, wywiadach z graczami i dyskusjach online.
\end{abstract}

Słowa kluczowe: gry bitewne, społeczność mowna, cykl życia gry 
